\title{
Effektiveness Jamuran Game to Increase the Children's Gross Skill at Pendidikan Anak Usia Dini Terpadu Tunas Bangsa Bukittinggi
}

\author{
Rakimahwatia , Ridha Fadila Putri ${ }^{\mathrm{b}}$ \\ Universitas Negeri Padang, Padang, Indonesia \\ e-mail:
}

\begin{abstract}
This research because of gross motor that is deficient. The purpose The aim of this study is to determine how effective the jamuran game to increase the children's gross motor skill at PAUD Terpadu Tunas Bangsa. The method used is quantitative approach, this study is an experiment with quasi experiment design. Sample of this research is PAUD terpadu Tunas Bangsa Bukittinggi. The results showed that the children in the experimental class doing the jamuran game have an average value higher than the control class that doing the engklek gunung game. It can be concluded that the hanger game is significantly effective towards the children's gross motor skill at PAUD Terpadu Tunas Bangsa Bukittinggi.
\end{abstract}

Keywords: jamuran game, gross motor skill

\section{INTRODUCTION}

Education is effort or activity that do deliberately, regularly, and planned with the intent to change or develop the desired behavior. In addition, education is also a basic need of children who must be fulfilled because every child is rightful to obtain education and teaching to shape the personality and intelligence in accordance with the interests and talents that exist in the child from an early age. According to Law No. 20 of 2003 on National Education System Article 1 point 14 states that Early Childhood Education is a coaching effort aimed at children from birth up to the age of six that is done through the provision of educational stimuli to assist the growth and development of the body and Spiritually so that children have readiness in entering further education held on formal, informal and informal channels.

The purpose of Early Childhood Education is to assist the child in developing various physical and psychological potentials that include morals and religious, emotional, cognitive, linguistic, physical / motor, autonomy and art values to be ready to enter basic education. One of Field of development that must be had by child is Physical motor development. This development consists of Gross motor and fine motor.

Children aged 3 to 6 years have good motor coordination skills. Motor skills can develop without being trained because of the influence of growth and maturity. Changes in skills like this only increase skills to a minimum, special training is required for this skill level to develop well. Activities that enhance gross motor skills in the form of coordination of body movements, such as running, jumping, jumping, hanging, throwing, catching, and maintaining balance

According to Sumantri (2005: 271) gross motor is a skill that is characterized by motion involving groups of large muscles as the main basis of movement. Sujiono (2009: 13) argues that gross motor movement is a skill that requires coordination of most parts of the child's body. Gross motor movements involve the activity of large muscles such as the muscles of the hands, leg muscles and the whole body of the child.

Gross motoric early childhood has not developed perfectly, therefore need to be trained through activities that are carried out in orderly and planned according to the stage of child development in a learning scene. Game is activity that pleasure for child, According to the principle of early childhood learning "playing while learning, learning while playing". Permainan

The game consists of modern games and traditional games. Traditional games are a form of game and or sporting activity that evolves from a certain community habit. The next developments the traditional game is often used as a type of game that has characteristics of the original regional and adapted to local cultural traditions. The activity was done to entertainment and done on free time for example after working, school etc. In practice the 
traditional game can incorporate elements of folk games and child games into it. It can even include activities that contain elements of art called traditional art.

According Mulyani (2013: 63) argues that the mushroom is a child game from Central Java and Yogyakarta that invites children gathered in the yard, clasped together to form a circle called jamuran (mushroom). Further Dharmamulya, et al (2008: 83) defines jamuran is a very popular game among children of Java, especially in the Daerah Istimewa Yogyakarta. Jamur means mushroom, and gets the end of "an". Jamur are round, jamuran games also visualize the shape of the round jamur, which is a circle. According to Fad (2014: 90-91) that the jamuran game can develop skills / skills skill, leadership, creativity, cooperation, strategy and insight of children. Dexterity developed in this mushroom game, such as a child can climb, jump, run well, run on a while, move around and etc.

Jamuran game can play in home field or school field. Jamuran games require only a piece of land (according to the number of players). Besides jamuran game also have a song accompaniment in singing by all jamuran players. The jamuran song is sung once every round. So when playing ten rounds then the song was sung as much as 10 times.

Thus it can be interpreted that the mushroom game is a hereditary game of ancestors containing cultural elements that are often played by children of ancient times, does not require any equipment and equipment is played in a circular way to form a circle and there is one child who is in the middle , While accompanied by a companion song, the circle is called mushroom. Researchers use the game mushrooms to develop rough motor child as well as agility. The dexterity in question is that children can move their muscles in play, such as running, jumping, walking on

\section{DISCUSSION}

This research use quantitative method with experiment type or quasi experiment research (quasi experiment). The research instrument used in this research is the test. The test will be valid if the test can measure what it wants to measure. With the criteria of assessment that is Very Good Developed score 4, Developed As Expected given a score of 3, Start Developed scored 2, Not Developed scored 1.
Table 1. Calculation Result of Liliefors Test of Experiment Class and Control Class (Pre-Test)

\begin{tabular}{ccccccc}
\hline No & Grup & $\mathbf{N}$ & $\boldsymbol{\alpha}$ & L0 & Lt & $\begin{array}{c}\text { Informatio } \\
\mathbf{n}\end{array}$ \\
1 & Experiment & 10 & 0,05 & 0,1987 & 0,258 & Normal \\
2 & Control & 10 & 0,05 & 0,2557 & 0,258 & Normal \\
\hline
\end{tabular}

Based on table 1, it can be seen that the experiment group get value of Lhitung0,1987 smaller than LTable 0,258 to $\alpha 0,05$. Thus the value of the experiment group comes from normally distributed data. Control group get value of Lhitung0,25571 smaller than LTable0,258 to $\alpha 0,05$. Thus the value of the control group comes from normally distributed data

The second test requirement is the homogeneity test using the Barlett test. This test is intended to determine whether the data came from a homogeneous group, between the experimental group and the control group. If chi squared count $<$ chi squared table means data coming from a homogeneous group.

This is in accordance with what Syafril proposes (2010: 208) that: "If the zalculation results of $\chi$ hitung smaller than $\chi$ Table thus That the data comes from a homogeneous group, but if $\chi$ hitung bigger than Table Then the group is not homogeneous". Calculation results obtained $x$ hitung is 2,07234 as in the following table :

Table 2. Pretest Homogeneity Test Result of Class of Experiment and Class of Control

\begin{tabular}{|c|c|c|c|c|}
\hline Class & A & $\chi_{\text {hitung }}^{2}$ & $\underset{\text { table }}{\chi^{2}}$ & $\begin{array}{c}\text { Conclusio } \\
\mathbf{n}\end{array}$ \\
\hline \multicolumn{5}{|c|}{ Experiment } \\
\hline Control & 0,05 & 2,07234 & 3,841 & Homogen \\
\hline
\end{tabular}

Base on Table 2 it is known that $\mathrm{x}^{2}$ hitung experiment group and control group smaller than Table ( $\mathrm{t}$ hitung $<\mathrm{t}$ Table), thus the experiment group and control group have a homogeneous variance.

After the normality and homogeneity test, it is known that the two sample classes are normally distributed and have homogeneous variance. Then it can be continued with hypothesis testing by using ttest technique. if thitung $>\boldsymbol{t}$ Table then $\mathrm{H}_{0}$ is rejected and $\mathrm{H}_{\mathrm{a}}$ is accepted

If $\boldsymbol{t}$ hitung $<\boldsymbol{t}$ Table then $\mathrm{H}_{0}$ is accepted dan $\mathrm{H}_{\mathrm{a}}$ is rejected 

test:

This is an overview of data processing with $\mathrm{t}$ -

Table 3. Calculation Result Of Pertest Value Of Experiment Class And Control Class

\begin{tabular}{ccc}
\hline Aspect & Experiment Group & Control Group \\
N & 10 & 10 \\
X & 64,375 & 63,125 \\
& 7,42 & 4,73 \\
\hline
\end{tabular}

$\mathrm{T}$ table for the real level $\alpha=0.05(5 \%)$ with $\mathrm{df}$ of 18 is $=2,10092$ Thus, it can be seen that at the real level $\alpha=0.05(5 \%)$, $\mathrm{t}$ hitung is smaller than $\mathrm{t}$ Table $(0.435<2.10092)$. Thus, it can be concluded that there is no significant difference between the creativity of the child in the experimental class and the control in the pre-test score.

Table 4. Calculation Result of Pre-test Testing with t-test

\begin{tabular}{|c|c|c|c|c|c|c|}
\hline No & Group & $\mathbf{N}$ & $\begin{array}{c}\text { Average } \\
\text { result }\end{array}$ & thitung & $\begin{array}{l}\text { tTable } \\
\propto 0,05\end{array}$ & Result \\
\hline 1 & $\begin{array}{c}\text { Experimen } \\
\mathrm{t}\end{array}$ & 10 & 64,375 & & & \\
\hline 2 & Control & 10 & 63,125 & 0,435 & 2,10092 & accept \\
\hline
\end{tabular}

$\mathrm{T}$ table for the real level $\alpha=0.05(5 \%)$ with $\mathrm{df}$ of 18 is $=2,10092$. Thus, it can be seen that at the real level $\alpha=0.05(5 \%), \mathrm{t}$ hitung is smaller than the $\mathrm{t}$ Table $(0.435<2.10092)$. Thus, it can be concluded that there was no significant difference between the pre-test results of gross motor development of children in the experimental group with the control group at PAUD Terpadu Tunas Bangsa Bukittinggi.

Based on test of experiment group normality and control group obtained value of $\mathrm{L} 0$ and $\mathrm{Lt}_{\mathrm{t}}$ at the real level of 0.05 for $\mathrm{N}=10$ as in the following table:

Table 5. Test Result Liliefors Post Test Experiment Class And Control Class

\begin{tabular}{ccccccc}
\hline No & Group & N & A & L0 & Lt & Information \\
1 & Experiment & 10 & 0,05 & 0,1418 & 0,258 & Normal \\
2 & Control & 10 & 0,05 & 0,1418 & 0,258 & Normal \\
\hline
\end{tabular}

Based on table 5 it can be seen that the experiment group L $L$ hitung value is $\mathbf{0 , 1 4 1 8}$ smaller than LTable is $\mathbf{0 , 2 5 8}$ for $\alpha 0,05$. Thus the value of the experimental group comes from normally distributed data. In the control group was obtained $L$ hitung is $\mathbf{0 , 1 4 1 8}$ smaller than $L$ Table is $\mathbf{0 , 2 5 8}$ for $\alpha 0,05$. This means that the control group data comes from normally distributed data.

Table 6. Post Test Homogenity Test of Experiment Class and Control Class

\begin{tabular}{crrrr}
\hline Group & A & $\begin{array}{c}\chi^{2} \\
\text { hitung }\end{array}$ & $\chi_{\text {able }}^{2}$ & Conclusion \\
Experiment & & & & \\
Control & 0,05 & 0 & 3,841 & Homogeneous \\
\hline
\end{tabular}

Based on table 6 known that $\mathrm{X}^{2}$ hitung experiment group and c o n trol group are smaller tahan $\mathrm{X}^{2}$ table value $\left(X^{2}\right.$ hitung $<X^{2}$ Table), means the experiment group and the control group have homogeneous variance.

Table 7. Calculation Result of Post Test Value of Experiment Class and Control Class

\begin{tabular}{ccc}
\hline Aspect & Experiment Group & Control Group \\
N & 10 & 10 \\
X & 88,75 & 76,25 \\
& 8,75 & 8,75 \\
\hline
\end{tabular}

$\mathrm{T}$ Table for the real level $\alpha=0.05$ (5\%) with $\mathrm{df}$ of 18 is $=2,10092$ Thus, it can be seen that at the real level $\alpha=0,05(5 \%)$, thitung is bigger than tTable $(3,03398>2,10092)$. Thus, it can be concluded that there is a significant difference between gross motor development of children in the experiment class that performs a jamuran game with a control class that performs engklek gunung game.

Table 8. Post-test Calculation Result Test with t-test

\begin{tabular}{|c|c|c|c|c|c|c|}
\hline No & Group & $\mathbf{N}$ & Average & t hitung & $\begin{array}{l}\text { t table } \\
\alpha 0,05\end{array}$ & Decision \\
\hline 1 & Experiment & 10 & 88,75 & & & \\
\hline 2 & Control & 10 & 76,25 & 3,03398 & 2,190092 & reject $\mathrm{H} 0$ \\
\hline
\end{tabular}

Based on the above table the experiment group obtained a higher value than the control group. Hypothesis test results obtained are thitung $>$ tTable that they are 3,03398 $>2,10092$ which is evidenced by a significant level $\alpha 0,05$ this means the hypothesisHa accepted dan Ho rejected, So there is a significant difference between the results of the gross motor development of the experiment group of children using jamuran games and control groups using the engklek gunung game at PAUD Terpadu 
Tunas Bangsa Bukittinggi. Thus it can be concluded that the jamuran ngame proved effective used for the development of child gross motor at PAUD Terpadu Tunas Bangsa Bukittinggi.

According Mulyani (2013: 63) argues that the mushroom is a child game from Central Java and Yogyakarta that invites children gathered in the yard, clasped together to form a circle called jamuran (mushroom). Further Dharmamulya, et al (2008: 83) defines jamuran is a very popular game among children of Java, especially in the Daerah Istimewa Yogyakarta. Jamur means mushroom, and gets the end of "an". Jamur are round, jamuran games also visualize the shape of the round jamur, which is a circle. According to Fad (2014: 90-91) that the jamuran game can develop skills / skills skill, leadership, creativity, cooperation, strategy and insight of children. Dexterity developed in this mushroom game, such as a child can climb, jump, run well, run on a while, move around and etc.

\section{CONCLUSIONS AND SUGGESTION}

The result of the research shows that there are significant differences of children's motor development at PAUD Terpadu Tunas Bangsa Bukittinggi, are between experiment class (B1) and control class (B2). It can be proven that with the game of jamuran proved effective against gross motor development in children, so the average value obtained from the experiment class is higher $(88,75)$ than the value of control class is $(76,25)$. Based on hypothesis test results obtained thitung $>$ tTable They are 3,03398>2,10092 which is evidenced by a significant level $\alpha \quad 0$, This means that there is a significant difference between the results of the gross motor development of the child in the experiment class that performs a jamuran game with a control class that performs engklek gunung game. Thus, the jamuran game proved to be effectively used to develop child gross motor.

\section{REFERENCES}

[1] Arikunto, Saharsimi. 2010. Prosedur Penelitian Suatu Pendekatan Praktik. Jakarta: Rineka Cipta

[2] Dharmamulya. 2008. Permainan Tradisional Jawa. Yogyakarta: Kepel Press

[3] Fad, Aisyah. 2014. Kumpulan Permainan Anak Tradisional Indonesia. Jakarta: Cerdas

[4] Interaktif (Penebar Swadaya Group)

[5] Mulyani. 2013. Permainan Tradisional Anak Indonesia. Yogyakarta: Langensari Publishing Sugiyono. 2012. Metode Penelitian Kuantitatif Kualitatif dan R\&D. Bandung: Alfabeta Sujiono, Bambang, dkk. 2009. Metode Pengembangan Keterampilan Motorik Anak Usia

[6] Dini. Jakarta: Departemen Pendidikan Nasional

[7] Sujiono, Dkk, 2010. Bermain Kreatif Berbasis Kecerdasan Jamak. Jakarta : Pt Indeks

[8] Sumantri. 2005. Model Pengembangan Keterampilan Motorik Anak Usia Dini. Jakarta: Departemen Pendidikan Nasional, Direktorat Pendidikan Tinggi, Direktorat Pembinaan Pendidikan Tenaga Kependidikan dan Ketenagaan Perguruan Tinggi

[9] Syafril. 2010. Statistika. Padang: SUKABINA Press. 